\title{
Determinants of Gender and Users' Level of Satisfactions with Circulation Policies in Academic Libraries in North-Central Zone of Nigeria
}

\author{
Umbur Demekaa ${ }^{1}$ and Bridget Demekaa ${ }^{2}$ \\ ${ }^{1}$ University Library and Information Services, Benue State University, Makurdi, Nigeria \\ ${ }^{2}$ University Library, University of Mkar, Nigeria \\ E-mail: udemekaa@yahoo.com
}

\begin{abstract}
The purpose of this study is to investigate determinants of users' level of satisfactions with circulation policies in academic libraries in the North Central Zone of Nigeria. A descriptive survey design was adopted for the study. The population comprised all the undergraduate registered users of the university libraries in the zone. The stratified random sampling technique was used to draw a sample of 600 registered library users for the study from four university libraries in the zone. A total of one research question were raised and one hypothesis formulated to guide the study. A self-constructed questionnaire entitled: "Determinants of Gender and Users' level of Satisfaction with Circulation Policies in Academic Libraries Questionnaire
\end{abstract} (DGULSCPALQ)" was the instrument used for data collection.

A reliability of the instrument was carried out using 100 registered users of the Delta State University Library, Abraka over a time lag of two weeks in order to determine its content and construct reliability. Data generated were analysed using Pearson's Product Moment Correlation, which yielded an $r$ of $\mathbf{0 . 8 0}$, which was considered adequate for the instrument. The data collected were analysed by using mean and standard deviation to answer the research question, while z-test statistical technique was used to test the formulated hypothesis at 0.05 level of significance. Findings revealed that Federal universities had moderate mean in the level of satisfaction with library opening hours than State owned Universities; The study also revealed that male library users had a high mean in the level of satisfaction with library opening hours on week days and a high mean score in level of satisfaction with the total number of cards issued for borrowing of items than female, there were no significant differences between federal and state universities in user's level of satisfaction with library holdings, borrowers' cards, loan period, fines and reservation.

There was no significant difference between federal and state owned universities except in user's level of satisfaction with library opening hours. Also, there was no significant difference between male and female users except in users' level of satisfaction with library loan periods. Finally, it was recommended that public university libraries in the North Central Zone of Nigeria should extend their opening hours on Sundays to make the users more satisfied with opening hours on that day; that the libraries should ensure that their circulation policies on fines for damaged and lost borrowed materials should reflect the present realities/cost of the items. Keywords: Level of Satisfactions with Circulation Policies in Academic Libraries

\section{INTRODUCTION}

The term gender refers to the significance a society attaches to biological categories of female and male. Gender is basic organizing principle of society that shapes how we think about ourselves and guide how we interact with other. Many scholars have discussed the issue of gender difference among students towards the use of library resources. Demekaa (2014) report that gender is associated with the use of electronic information resources, and that male postgraduate students were more likely to use e-resources than female students. He further report that even when there was control for attitude towards the use of e-resources, or training in the use of e-resources, the relationship between gender and e-resources was maintained.

\section{LITERATURE REVIEW}

A study by Tella and Mutula (2008) on gender difference in computer literacy report that students with higher computer literacy were more inclined to access and make use of library facilities. They further report that differences exist between female and male graduate students at the University of Botswana with regard to computer literacy. In the same vein, Ford and Miller (1996) report that gender is a predictor of internet use and attitudes that males seem to enjoy browsing on the internet for enjoyment, while females tend to only use it for work-related purposes. Ford, Miller and Moss (2001) found that women tend to experience more difficulty in finding information online than men.

Also, Hiller (2001) survey asked whether libraries were open when needed on evenings, weekends, summer, and interim periods. Male respondents, as the case with the previous survey, had a lower satisfaction. When asked to choose from a list of priorities, more than $37 \%$ of female respondents and $42 \%$ of male respondents chose increased library hours. Male respondents also wrote more comments about hours than the female respondents.

Abdulrahman, Mahmud and Jamaludin (n.d.) studied age, gender and race differences in the usage of digital library among Malaysian postgraduate students. The study describes the differences in the usage of digital library 
between gender groups among the postgraduate students at the Malaysian intensive research universities. The purpose was to determine whether differences in the usage of digital library exist between different characteristics and background. The study found that there was no evidence of a significant difference in the mean usage of digital library between male and female postgraduate students.

Igun (2010) reported a collection between the level of human development and the prevalence of network technologies' access and use. She said that countries with high human development indices are more likely to have high network technology utilization. Although, she further stated that women are now using the network technology and the internet, a greater number of female librarians are not very familiar with it like their male counterparts which can be referred to as gender digital divide. Female participation in the use of networks, particularly in the developing countries of the world lags behind that of men thereby widening the gender divide (Women in the Information Society, 2005).

Naidu (2009) studied users' satisfaction with library facilities. A total of 251 (20.8\%) males indicated dissatisfaction and 82 (6.7\%) female were very satisfied with the library facilities. She also revealed that $(6.7 \%)$ academic staff were very satisfied with library facilities, while $5(11.1 \%)$ indicated their dissatisfaction with the library facilities.

\section{SIGNIFICANCE OF THE STUDY}

This study intends to present information on users' satisfaction towards library policies. It is hoped that the study will be of benefit to the library services, librarian profession, and serve as a contribution to the body of knowledge in the area of user satisfaction on libraries' contribution and their services to users. The general purpose of this study will help both staff and users (undergraduate) to understand how library policies are being used to improve the types of materials that are allowed on loan, opening hours on Sundays, and process of obtaining library cards, time materials on reservation are allowed on loan to undergraduate library users.

\section{SCOPE AND DELIMITATION OF THE STUDY}

This study focuses on users' level of satisfaction with circulation policies in the four public university libraries in the six state of north central Nigeria. It explores the users' levels of satisfaction with circulation policies, by finding out if there is significant difference with category of users' satisfaction by ownership of university libraries (Federal and state) and gender regarding circulation policies on library holdings, library opening hours, library borrowers' cards, library loan periods, library fines and library reservation. The North Central Zone is located in the central of Nigeria and has six states in the zone.
Research Question: What is the level of male and female library users' satisfaction regarding circulation policies?

Research Hypothesis: There is no significant difference between male and female library users' levels of satisfaction with circulation policies in the university libraries?

Purpose of the Study: Determine if there is significant difference in users' satisfaction with circulation policies due to gender.

\section{RESEARCH METHODOLOGY}

A total of 600 copies of the questionnaire were administered to the student users of the various university libraries under study. The questionnaire was administered and retrieved within one month. The data obtained from questionnaire were analysed using frequency counts, mean and standard deviation to answer the research question and $z$-test statistical technique was used to test the one formulated hypothesis. The levels of satisfaction from $3.50-4.00$ were rated as high, while $2.50-3.49$ as moderate and $2.49-1.00$ as low. It was used here because the study involved the comparison of two groups (federal and state universities) and the sample size was large.

\section{RESULTS AND DISCUSSION}

Table I shows the mean and standard deviation of users' satisfaction with circulation policies by male and female respondents with respect to holdings. The mean for users' level of satisfaction is highest for types of materials that are allowed on loan/in open/access/in circulation. The materials are mostly textbooks, fiction and non-fiction devoted to circular offering of the institutions. The data generally show that users are satisfied with the libraries circulation policies on holdings. This finding corroborates that of Sacchelti (2011) and Ezeala and Yusuf (2011) but does not corroborate Kassim (2009).

Table I reveals that users' level of satisfaction with opening hours generally attracted moderate mean scores for library users. The analysis generally shows that users were satisfied with circulation policies on library opening hours. This finding corroborates that of Senevirantone (2006) in which majority of the users at the Postgraduate Institute of Medicine Branch Library at Peradeniya were satisfied with the opening hours on week days.

Table I also reveals the total number of cards registered users (students) are issued for borrowing of books and other items attracted the high mean of 3.51 for male and with moderate mean score of 3.38 for female. Borrowers' cards are tickets prepared for borrowers. This finding is in line with Sirinvasaln and Reddy (2010) who discovered that users were satisfied with total number of borrowers' tickets they were issued by the Medical College Libraries in Andhra Pradesh, India. 
TABLE I MEAN AND STANDARD DEVIATION OF USERS' LEVELS OF SATISFACTION BY GENDER

\begin{tabular}{|c|c|c|c|c|c|c|c|}
\hline Components & $\mathbf{S} / \mathbf{N}$ & Items & Gender & $\mathbf{N}$ & $\bar{X}$ & SD & Satisfaction Level \\
\hline \multirow[t]{5}{*}{$\begin{array}{c}\text { Library } \\
\text { Holdings } \\
\end{array}$} & 1 & Open circulation materials & $\begin{array}{c}\text { Male } \\
\text { Female }\end{array}$ & $\begin{array}{l}368 \\
194\end{array}$ & $\begin{array}{l}3.53 \\
3.39\end{array}$ & $\begin{array}{l}.67 \\
.68\end{array}$ & $\begin{array}{c}\text { High } \\
\text { Moderate }\end{array}$ \\
\hline & 2. & Materials not allowed on loan & $\begin{array}{c}\text { Male } \\
\text { Female }\end{array}$ & $\begin{array}{l}368 \\
194 \\
\end{array}$ & $\begin{array}{c}3.05 \\
3.3 .16 \\
\end{array}$ & $\begin{array}{l}.66 \\
.71 \\
\end{array}$ & $\begin{array}{l}\text { Moderate } \\
\text { Moderate }\end{array}$ \\
\hline & 3 & Available circulatory materials & $\begin{array}{c}\text { Male } \\
\text { Female }\end{array}$ & $\begin{array}{l}368 \\
194 \\
\end{array}$ & $\begin{array}{l}2.91 \\
3.02 \\
\end{array}$ & $\begin{array}{l}.78 \\
.79\end{array}$ & $\begin{array}{l}\text { Moderate } \\
\text { Moderate }\end{array}$ \\
\hline & 4 & $\begin{array}{l}\text { Materials not allowed in Closed } \\
\text { access }\end{array}$ & $\begin{array}{c}\text { Male } \\
\text { Female }\end{array}$ & $\begin{array}{l}368 \\
194 \\
\end{array}$ & $\begin{array}{l}3.03 \\
3.05 \\
\end{array}$ & $\begin{array}{l}.85 \\
.85\end{array}$ & $\begin{array}{l}\text { Moderate } \\
\text { Moderate }\end{array}$ \\
\hline & 5 & Maximum borrowing opportunity & $\begin{array}{c}\text { Male } \\
\text { Female }\end{array}$ & $\begin{array}{l}368 \\
194 \\
\end{array}$ & $\begin{array}{l}3.17 \\
3.23 \\
\end{array}$ & $\begin{array}{l}.79 \\
.83\end{array}$ & $\begin{array}{l}\text { Moderate } \\
\text { Moderate }\end{array}$ \\
\hline \multirow[t]{6}{*}{$\begin{array}{l}\text { Opening } \\
\text { Hours }\end{array}$} & 1 & Weekly Opening hours & $\begin{array}{c}\text { Male } \\
\text { Female }\end{array}$ & $\begin{array}{l}368 \\
194 \\
\end{array}$ & $\begin{array}{l}3.30 \\
3.31 \\
\end{array}$ & $\begin{array}{l}.67 \\
.66 \\
\end{array}$ & $\begin{array}{l}\text { Moderate } \\
\text { Moderate }\end{array}$ \\
\hline & 2 & Saturday opening hours & $\begin{array}{c}\text { Male } \\
\text { Female }\end{array}$ & $\begin{array}{l}368 \\
194\end{array}$ & $\begin{array}{ll}3.14 \\
3.21\end{array}$ & $\begin{array}{l}.77 \\
.77\end{array}$ & $\begin{array}{l}\text { Moderate } \\
\text { Moderate }\end{array}$ \\
\hline & 3 & Sunday opening hours & $\begin{array}{c}\text { Male } \\
\text { Female }\end{array}$ & $\begin{array}{l}368 \\
194 \\
\end{array}$ & $\begin{array}{l}2.86 \\
2.92 \\
\end{array}$ & $\begin{array}{l}.86 \\
.84\end{array}$ & $\begin{array}{l}\text { Moderate } \\
\text { Moderate }\end{array}$ \\
\hline & 4 & Public holiday opening hours & $\begin{array}{c}\text { Male } \\
\text { Female }\end{array}$ & $\begin{array}{l}368 \\
194 \\
\end{array}$ & $\begin{array}{l}2.96 \\
2.94 \\
\end{array}$ & $\begin{array}{l}.87 \\
.82\end{array}$ & $\begin{array}{l}\text { Moderate } \\
\text { Moderate }\end{array}$ \\
\hline & 5 & Examination period opening hours & $\begin{array}{c}\text { Male } \\
\text { Female }\end{array}$ & $\begin{array}{l}368 \\
194 \\
\end{array}$ & $\begin{array}{l}3.07 \\
3.04 \\
\end{array}$ & $\begin{array}{l}.78 \\
.85\end{array}$ & $\begin{array}{l}\text { Moderate } \\
\text { Moderate }\end{array}$ \\
\hline & 6 & Vacations period opening hours & $\begin{array}{c}\text { Male } \\
\text { Female }\end{array}$ & $\begin{array}{l}368 \\
194\end{array}$ & $\begin{array}{ll}3.14 \\
3.08\end{array}$ & $\begin{array}{l}.79 \\
.77\end{array}$ & $\begin{array}{l}\text { Moderate } \\
\text { Moderate }\end{array}$ \\
\hline \multirow[t]{5}{*}{$\begin{array}{l}\text { Borrowers } \\
\text { Cards }\end{array}$} & 1 & $\begin{array}{l}\text { Number of registered cards for } \\
\text { borrowing }\end{array}$ & $\begin{array}{l}\text { Male } \\
\text { Female }\end{array}$ & $\begin{array}{l}368 \\
194 \\
\end{array}$ & $\begin{array}{l}3.51 \\
3.38 \\
\end{array}$ & $\begin{array}{l}.65 \\
.60 \\
\end{array}$ & $\begin{array}{c}\text { High } \\
\text { Moderate }\end{array}$ \\
\hline & 2 & Process of cards obtainable & $\begin{array}{c}\text { Male } \\
\text { Female }\end{array}$ & $\begin{array}{l}368 \\
194 \\
\end{array}$ & $\begin{array}{l}3.12 \\
3.16 \\
\end{array}$ & $\begin{array}{l}.68 \\
.63 \\
\end{array}$ & $\begin{array}{l}\text { Moderate } \\
\text { Moderate }\end{array}$ \\
\hline & 3 & Financial cost of borrowers ' cards & $\begin{array}{c}\text { Male } \\
\text { Female }\end{array}$ & $\begin{array}{l}368 \\
194 \\
\end{array}$ & $\begin{array}{l}3.14 \\
3.10\end{array}$ & $\begin{array}{l}.78 \\
.67\end{array}$ & $\begin{array}{l}\text { Moderate } \\
\text { Moderate }\end{array}$ \\
\hline & 4 & Financial cost of lost cards & $\begin{array}{c}\text { Male } \\
\text { Female }\end{array}$ & $\begin{array}{l}368 \\
194 \\
\end{array}$ & $\begin{array}{l}2.99 \\
3.11 \\
\end{array}$ & $\begin{array}{l}.84 \\
.76\end{array}$ & $\begin{array}{l}\text { Moderate } \\
\text { Moderate }\end{array}$ \\
\hline & 5 & Process of card replacement & $\begin{array}{c}\text { Male } \\
\text { Female }\end{array}$ & $\begin{array}{l}368 \\
194\end{array}$ & $\begin{array}{l}3.07 \\
3.03\end{array}$ & $\begin{array}{l}.77 \\
.75\end{array}$ & $\begin{array}{l}\text { Moderate } \\
\text { Moderate }\end{array}$ \\
\hline Loan Period & 1 & Duration of material borrowing & $\begin{array}{c}\text { Male } \\
\text { Female }\end{array}$ & $\begin{array}{l}368 \\
194\end{array}$ & $\begin{array}{l}3.29 \\
3.28\end{array}$ & $\begin{array}{l}.62 \\
.62\end{array}$ & $\begin{array}{l}\text { Moderate } \\
\text { Moderate }\end{array}$ \\
\hline & 2 & $\begin{array}{l}\text { Reserved materials borrowing } \\
\text { period within the library }\end{array}$ & $\begin{array}{c}\text { Male } \\
\text { Female }\end{array}$ & $\begin{array}{l}368 \\
194 \\
\end{array}$ & $\begin{array}{l}2.23 \\
3.22 \\
\end{array}$ & $\begin{array}{l}.73 \\
.70\end{array}$ & $\begin{array}{c}\text { Low } \\
\text { Moderate }\end{array}$ \\
\hline & 3 & $\begin{array}{l}\text { Duration of reserved materials } \\
\text { allowed for home use }\end{array}$ & $\begin{array}{c}\text { Male } \\
\text { Female }\end{array}$ & $\begin{array}{l}368 \\
194\end{array}$ & $\begin{array}{l}2.07 \\
2.99\end{array}$ & $\begin{array}{l}.79 \\
.68\end{array}$ & $\begin{array}{c}\text { Low } \\
\text { Moderate }\end{array}$ \\
\hline & 4 & $\begin{array}{l}\text { Duration of project borrowing } \\
\text { within the library }\end{array}$ & $\begin{array}{c}\text { Male } \\
\text { Female } \\
\end{array}$ & $\begin{array}{l}368 \\
194 \\
\end{array}$ & $\begin{array}{l}3.11 \\
2.93 \\
\end{array}$ & $\begin{array}{l}.78 \\
.78 \\
\end{array}$ & $\begin{array}{l}\text { Moderate } \\
\text { Moderate } \\
\end{array}$ \\
\hline & 5 & Frequency of item renewal & $\begin{array}{c}\text { Male } \\
\text { Female }\end{array}$ & $\begin{array}{ll}368 \\
194 \\
\end{array}$ & $\begin{array}{ll}3.13 \\
3.07\end{array}$ & $\begin{array}{l}.70 \\
.73 \\
\end{array}$ & $\begin{array}{l}\text { Moderate } \\
\text { Moderate }\end{array}$ \\
\hline & 6 & Channels of Patron renewal & $\begin{array}{c}\text { Male } \\
\text { Female }\end{array}$ & $\begin{array}{l}368 \\
194\end{array}$ & $\begin{array}{ll}3.29 \\
3.13\end{array}$ & $\begin{array}{l}.74 \\
.73\end{array}$ & $\begin{array}{l}\text { Moderate } \\
\text { Moderate }\end{array}$ \\
\hline & 7 & $\begin{array}{l}\text { Procedure for renewing borrowed } \\
\text { items }\end{array}$ & $\begin{array}{c}\text { Male } \\
\text { Female }\end{array}$ & $\begin{array}{l}368 \\
194\end{array}$ & $\begin{array}{l}3.17 \\
3.14\end{array}$ & $\begin{array}{l}.72 \\
.66\end{array}$ & $\begin{array}{l}\text { Moderate } \\
\text { Moderate }\end{array}$ \\
\hline & 8 & $\begin{array}{l}\text { Holding policy of borrowed items at } \\
\text { circulation desk }\end{array}$ & $\begin{array}{c}\text { Male } \\
\text { Female }\end{array}$ & $\begin{array}{l}368 \\
194\end{array}$ & $\begin{array}{l}3.05 \\
2.99\end{array}$ & $\begin{array}{l}.77 \\
.71 \\
\end{array}$ & $\begin{array}{l}\text { Moderate } \\
\text { Moderate }\end{array}$ \\
\hline & 9 & Recalling policy before expiration & $\begin{array}{c}\text { Male } \\
\text { Female }\end{array}$ & $\begin{array}{l}368 \\
194\end{array}$ & $\begin{array}{l}3.15 \\
3.07\end{array}$ & $\begin{array}{l}.80 \\
.80\end{array}$ & $\begin{array}{l}\text { Moderate } \\
\text { Moderate }\end{array}$ \\
\hline & 10 & Notification policy of held items & $\begin{array}{c}\text { Male } \\
\text { Female }\end{array}$ & $\begin{array}{l}368 \\
194\end{array}$ & $\begin{array}{l}3.19 \\
3.11 \\
\end{array}$ & $\begin{array}{l}.76 \\
.72\end{array}$ & $\begin{array}{l}\text { Moderate } \\
\text { Moderate }\end{array}$ \\
\hline Library Fines & 1 & Fine for overdue books /materials & $\begin{array}{c}\text { Male } \\
\text { Female }\end{array}$ & $\begin{array}{l}368 \\
194\end{array}$ & $\begin{array}{l}3.42 \\
3.40\end{array}$ & $\begin{array}{l}.72 \\
.70\end{array}$ & $\begin{array}{l}\text { Moderate } \\
\text { Moderate }\end{array}$ \\
\hline & 2 & Fine paid for lost items & $\begin{array}{c}\text { Male } \\
\text { Female }\end{array}$ & $\begin{array}{l}368 \\
194\end{array}$ & $\begin{array}{l}3.20 \\
3.16\end{array}$ & $\begin{array}{l}.74 \\
.80\end{array}$ & $\begin{array}{l}\text { Moderate } \\
\text { Moderate }\end{array}$ \\
\hline & 3 & Fine for damaged items & $\begin{array}{c}\text { Male } \\
\text { Female }\end{array}$ & $\begin{array}{l}368 \\
194 \\
\end{array}$ & $\begin{array}{l}3.05 \\
3.11 \\
\end{array}$ & $\begin{array}{l}.84 \\
.77\end{array}$ & $\begin{array}{l}\text { Moderate } \\
\text { Moderate }\end{array}$ \\
\hline & 4 & $\begin{array}{l}\text { Borrower's financial liability for } \\
\text { lost materials }\end{array}$ & $\begin{array}{c}\text { Male } \\
\text { Female }\end{array}$ & $\begin{array}{l}368 \\
194 \\
\end{array}$ & $\begin{array}{ll}3.16 \\
3.12 \\
\end{array}$ & $\begin{array}{l}.80 \\
.79\end{array}$ & $\begin{array}{l}\text { Moderate } \\
\text { Moderate }\end{array}$ \\
\hline
\end{tabular}




\begin{tabular}{|c|c|c|c|c|c|c|c|}
\hline Components & $\mathbf{S} / \mathbf{N}$ & Items & Gender & $\mathbf{N}$ & $\bar{X}$ & SD & Satisfaction Level \\
\hline \multirow[t]{5}{*}{$\begin{array}{c}\text { Library } \\
\text { Reservation }\end{array}$} & 1 & The location of the research section & $\begin{array}{c}\text { Male } \\
\text { Female }\end{array}$ & $\begin{array}{l}368 \\
194 \\
\end{array}$ & $\begin{array}{l}3.48 \\
3.40\end{array}$ & $\begin{array}{l}.76 \\
.79\end{array}$ & $\begin{array}{l}\text { Moderate } \\
\text { Moderate } \\
\end{array}$ \\
\hline & 2 & Borrowing of reserved items & $\begin{array}{c}\text { Male } \\
\text { Female }\end{array}$ & $\begin{array}{l}368 \\
194 \\
\end{array}$ & $\begin{array}{l}3.10 \\
3.11\end{array}$ & $\begin{array}{l}.69 \\
.67 \\
\end{array}$ & $\begin{array}{l}\text { Moderate } \\
\text { Moderate }\end{array}$ \\
\hline & 3 & $\begin{array}{l}\text { Number of borrowed reserved } \\
\text { books }\end{array}$ & $\begin{array}{c}\text { Male } \\
\text { Female }\end{array}$ & $\begin{array}{l}368 \\
194 \\
\end{array}$ & $\begin{array}{l}3.07 \\
3.06\end{array}$ & $\begin{array}{l}.88 \\
.84\end{array}$ & $\begin{array}{l}\text { Moderate } \\
\text { Moderate }\end{array}$ \\
\hline & 4 & $\begin{array}{l}\text { The duration of borrowing books } \\
\text { on reservation }\end{array}$ & $\begin{array}{c}\text { Male } \\
\text { Female }\end{array}$ & $\begin{array}{l}368 \\
194\end{array}$ & $\begin{array}{l}3.09 \\
3.19\end{array}$ & $\begin{array}{l}.85 \\
.71\end{array}$ & $\begin{array}{l}\text { Moderate } \\
\text { Moderate }\end{array}$ \\
\hline & 5 & $\begin{array}{l}\text { The way reserved materials are } \\
\text { recorded }\end{array}$ & $\begin{array}{c}\text { Male } \\
\text { Female } \\
\end{array}$ & $\begin{array}{l}368 \\
194 \\
\end{array}$ & $\begin{array}{l}3.27 \\
3.22 \\
\end{array}$ & $\begin{array}{l}.83 \\
.78 \\
\end{array}$ & $\begin{array}{l}\text { Moderate } \\
\text { Moderate }\end{array}$ \\
\hline
\end{tabular}

The Table also indicates users' level of satisfaction with circulation policies on loan period. The time/duration materials on reservation are allowed for home use attracted low mean for male (2.07) and female (2.99) users with the latter slightly higher than the former. This finding corroborates Ezeala and Yusuf (2011) study in which respondents of Nigerian agricultural research institute libraries is to ensure that borrowed materials are returned on due data that they can be available for the user of other library users. Thus the respondents in this study would like other users to have access to materials when due for return.

The mean for level of satisfaction with the time/duration materials on reservation are allowed on loan within the library attracted also low mean for male (2.23) and a moderate mean score for female (3.22) users. The respondents in this study are satisfied with this policy. However, the mean for user satisfaction with the policy of holding a material(s) returned/borrowed at the circulation desk was also moderate for male (3.05) and female (2.99) library users. In some libraries, borrowed materials that have been returned can be left in the circulation desk for a specific period of time before being taken to stacks for shelving. This practice is not satisfactory to some of the respondents.
Table I reveals that male and female users' satisfaction with library fines attracted moderate mean scores for all the respondents in the university libraries. The amount paid for books/materials, amount paid for lost items or damaged items were found satisfactory by the respondents. This shows that users are satisfied with the charges and are encouraged with the policies and thereby make the materials (book borrowed) available to more library users as they returned them on the date due. The respondents' moderate level of satisfaction with overdue fines could be due to low amount charged as overdue fines (Zaki, 1994; Adomi, Nwalo, 2003; Nina-Okposung, 2011). The finding of this study corroborates Adomi (2003) who found that some users of Delta State University were satisfied with fines because they force users to return borrowed items promptly. Table I also shows the mean and standard deviation of users' level of satisfaction with the library reservation by library users. From the table, the location of the research section attracted a moderate mean score of 3.48 for male and 3.40 for female users. The table reveals general satisfaction with reservation. This finding corroborates that by Seneviratne (2006) whose respondents were satisfied with book reservation.

TABLE II Z-TEST ANALYSIS OF MALE AND FEMALE USERS’ LEVEL OF SATISFACTION WITH CIRCULATION POLICIES IN ACADEMIC LIBRARIES

\begin{tabular}{|c|c|c|c|c|c|c|c|c|c|}
\hline Components & Gender & $\mathbf{N}$ & $\bar{X}$ & SD & df & $\begin{array}{c}\mathrm{z}- \\
\text { calculated } \\
\text { value }\end{array}$ & $\begin{array}{l}\text { z-critical } \\
\text { value }\end{array}$ & $\begin{array}{c}\text { Level of } \\
\text { significance }\end{array}$ & Remark \\
\hline \multirow{2}{*}{ Holdings } & Male & 368 & 15.70 & 2.14 & \multirow{2}{*}{560} & \multirow{2}{*}{-.81} & \multirow{2}{*}{1.96} & \multirow{2}{*}{0.05} & \multirow{2}{*}{ Not significant } \\
\hline & Female & 194 & 15.86 & 2.27 & & & & & \\
\hline \multirow{2}{*}{ Opening Hours } & Male & 368 & 18.47 & 2.53 & \multirow{2}{*}{560} & \multirow{2}{*}{-.17} & \multirow{2}{*}{1.96} & \multirow{2}{*}{0.05} & \multirow{2}{*}{ Not significant } \\
\hline & Female & 194 & 18.51 & 2.48 & & & & & \\
\hline \multirow{2}{*}{ Borrowers' Cards } & Male & 368 & 15.82 & 2.16 & \multirow{2}{*}{560} & \multirow{2}{*}{.18} & \multirow{2}{*}{1.96} & \multirow{2}{*}{0.05} & \multirow{2}{*}{ Not significant } \\
\hline & Female & 194 & 15.78 & 1.93 & & & & & \\
\hline \multirow{2}{*}{ Loan periods } & Male & 368 & 31.68 & 3.56 & \multirow{2}{*}{560} & \multirow{2}{*}{2.43} & \multirow{2}{*}{1.96} & \multirow{2}{*}{0.05} & \multirow{2}{*}{ Significant } \\
\hline & Female & 194 & 30.95 & 3.45 & & & & & \\
\hline \multirow{2}{*}{ Fines } & Male & 368 & 12.82 & 2.12 & \multirow{2}{*}{560} & \multirow{2}{*}{.23} & \multirow{2}{*}{1.96} & \multirow{2}{*}{0.05} & \multirow{2}{*}{ Not significant } \\
\hline & Female & 194 & 12.79 & 1.92 & & & & & \\
\hline \multirow{2}{*}{ Reservation } & Male & 368 & 15.98 & 2.42 & \multirow{2}{*}{560} & \multirow{2}{*}{.04} & \multirow{2}{*}{1.96} & \multirow{2}{*}{0.05} & \multirow{2}{*}{ Not significant } \\
\hline & Female & 194 & 15.69 & 1.84 & & & & & \\
\hline
\end{tabular}


The data in Table II shows that the calculated $z$-value is -.81 and the $\mathrm{z}$-critical value is 1.96 at $\mathrm{df}$ of 560 . The calculated z-value is less than the critical z-value. Therefore the null hypothesis which states earlier that there is no significant difference between male and female in users' levels of satisfaction on library holdings in federal and state universities is retained. The finding agrees with Demekaa (2015) and Sacchelti (2011) which found that male and female (students) users were satisfied with books in the collection because they found the books useful and relevant to their research area.

Table II also shows that the calculated $\mathrm{z}$-value is -.17 and the $\mathrm{z}$-critical value is 1.96 at df of 560 . The calculated $\mathrm{z}$ value is less than the critical $z$-value. Therefore, the null hypothesis which states earlier that there is no significant difference between male and female in the users' levels of satisfaction on opening hours in federal and state universities is retained.

\section{SUMMARY OF THE STUDY}

This study set out to explore users' satisfaction with circulation policies in public university libraries in the North Central Zone of Nigeria. A total of 4 (2 federal and 2 state) university libraries were randomly selected from 10 Universities located in the North Central Zone of Nigeria. These were University of Jos Library, federal University of Technology Library, Minna, Benue State University Library, Makurdi, and Kogi State University Library, Ayangba.

The actual users of each of the university libraries were used for the study. A systematic sampling technique was used to draw a sample of 562 respondents used for the study. In each of university libraries, a copy of questionnaire was administered to every fifth person who sat in the library to make use of the services of each library. A total of one research question was answered and one null hypotheses was tested in the study.

Below is a summary of the findings of the study

1. The respondents were generally satisfied with circulation policies on library holdings, opening hours, borrowers' cards, loan period, library fines and reservation.

2. The male and female respondents from federal and state universities were generally satisfied with the library circulation policies on holdings, opening hours, borrowers' cards, loan periods, library fines and reservation.

\section{CONCLUSION}

Based on the findings of the study, it was concluded that there is no significant difference between federal and state universities in users' level of satisfaction with library circulation policies on holdings, library borrowers' cards, library loan period, library fines and library reservation. The findings also showed that there were no significant difference between male and female in federal and state universities users' levels of satisfaction with library circulation policies on holdings, opening hours, borrowers' cards, library fines, and library reservation.

\section{REFERENCES}

[1] Abdulrahman, A., Mahmud, Z. \& Jamaludin, A. (n.d.) Age, gender and race differences in the usage of digital library among Malaysian postgraduate students. Recent Researches in Education. 137-140.

[2] Adomi, E.E. (2003). Attitudes of university library users towards overdue fines in Nigeria. The Bottom Line: Managing Library Finances, 16(1), 19-24.

[3] Demekaa, U. Tyonum, N.M. and Demekaa, B (2015) Enhancing of User's Satisfaction with Circulation Policies in Public University Libraries in Nigeria. Asian Journal of Information Science Technology. Vol.5:2. 19-27. (Asian). www.trp.org.in.

[4] Ezeala, L.O. \& Yusuf, E.O. (2011). Users satisfaction with library resources and services in Nigeria Agricultural Research Institute Library Philosophy and Practice. Retrieved from http://unllib.unl.edu/LPP/.

[5] Ford, N., Miller, D. \& Moss, N. (2001).The role of individual difference in Internet searching: an empirical study. Journal of the American Society of Information Science and Technology, 52(12), 1049-1066.

[6] Hiller, S. (2001). Assessing users' needs, satisfaction and library performance at the University of Washington libraries. Library Trends, 49(4), 605-625.

[7] Kassim, N. A. (2009). Evaluating users' satisfaction on academic library performance. Malaysian Journal of Library \& Information Science, 14 (2), 101-115.

[8] Mandal, P.A. \& Mulkangard, F. (2007). Gender analysis of electronic information resources use: a case of the University of Dares Salaam, Tanzania. University of Dares Salaam Library Journal, 9(1), 30-52.

[9] Mil, H.V. (2009), Borrowing library book online: A study to establish potential demand. Policies of MLA council. Retrieved http://www.mla.gov.uk/what/policy-development/currentconsultains /-/media/files/pdf/2009/LLO-report-HVM-revised/May 09 FINAL.

[10] Museums, Libraries and Archives Council (2009). Retrieved from http://www.mla.gov.uk/what/policy-development/_current consultatins/-/media/files/pdf/2009/LLO-Report-HVM-revised/May 09 FINAL.

[11] Naidu, Y. (2009). User perceptions of service quality and the level of user satisfaction at the Mangosuthu University of Technology Library, Umlazi Durban. Unpublished MIS Thesis, Department of Sociology and Social Studies, University of Kwazulu-Natal, Pietermaritzburg, South Africa.

[12] Nina-Okposung, M.O. (2011). Library policies and overdue materials in Delta State Polytechnic Libraries, Nigeria. Journal of Research in Education and Society, 2(1), 199-207. Retrieved from http://www. icidr.org/doc/ICIDR PDF contents/journal of research in education and society.

[13] Nwalo, K.I.N. (2003). Fundamentals of library practice. A manual on library routines. Ibadan: Stirling Horden Publishers.

[14] Sacchelti, L. (2011). How to use statistics to survive a personal story. Performance Measurement and Metric, 12(1), 78-86.

[15] Seneviratne, D. (2006). Measuring user satisfaction: a case study at the PGIM branch library at Peradeniya. Journals of the University Librarians Association of Sri Lanka.

[16] Tella, A., \& Mutula, S. M. (2008). Gender differences in computer literacy among undergraduate students at the University of Botswana: Implications for the library use.

[17] Zaki, M. M. (1994). Delinquency in Ahmadu Bello University Library, Zaria Journal of Librarianship, 1(1\&2), 102-109. 